Original article

DOI: $10.2478 / 10004-1254-65-2014-2513$

\title{
Antihaemolytic activity of thirty herbal extracts in mouse red blood cells
}

\author{
Masoumeh Khalili ${ }^{1}$, Mohammad Ali Ebrahimzadeh ${ }^{1}$, and Yaghoub Safdari² \\ Pharmaceutical Sciences Research Center, School of Pharmacy, Mazandaran University of Medical Sciences, Sari ${ }^{1}$, \\ Faculty of Advanced Medical Technologies, Golestan University of Medical Sciences, Gorgan², Iran
}

Received in March 2014

CrossChecked in March 2014

Accepted in November 2014

\begin{abstract}
Reactive oxygen species (ROS) can lead to haemolysis and eventually to diseases such as thalassemia and sickle cell anaemia. Their action can be counteracted by the antihaemolytic activity of therapeutic agents. The aim of our study was to identify plants that most efficiently counteract ROS-caused haemolysis. From ten plants known for their antioxidant activity (Orobanche orientalis G. Beck, Cucumis melo L., Albizzia julibrissin Durazz, Galium verum L., Scutellaria tournefortii Benth, Crocus caspius Fischer \& Meyer, Sambucus ebulus L., Danae racemosa L., Rubus fruticsos L., and Artemisia absinthium L.) we prepared 30 extracts using three extraction methods (percolation, Soxhlet, and ultrasound-assisted extraction) to see whether the extraction method affects antihaemolytic efficiency, and one extraction method (polyphenol extraction) to see how much of this action is phenol-related. Extract antihaemolytic activity was determined in mice red blood cells and compared to that of vitamin $\mathrm{C}$ as a known antioxidant. Nine of our extracts were more potent than vitamin $\mathrm{C}$, of which G. verum (aerial parts/percolation) and $S$. tournefortii (aerial parts/polyphenol) extracts were the most potent, with an $\mathrm{IC}_{50}$ of 1.32 and $2.08 \mu \mathrm{g} \mathrm{mL} \mathrm{m}^{-1}$, respectively. Haemolysis inhibition depended on extract concentration and the method of extraction. These plants could provide accessible sources of natural antioxidants to the pharmaceutical industry.
\end{abstract}

KEY WORDS: Galium verum; hydrogen peroxide; percolation; phenols; Scutellaria tournefortii; Soxhlet; ultrasound-assisted extraction

Oxidative damage and haemolysis caused by reactive oxygen species (ROS) have a major role in the development of diseases such as thalassemia, glucose-6-phosphate dehydrogenase deficiency, and sickle cell anaemia. Red blood cells (RBCs) are the primary targets of free radicals, owing to their high membrane concentrations of polyunsaturated fatty acids (linoleic and arachidonic acids in particular) and $\mathrm{O}_{2}$ transport associated with redox active haemoglobin molecules, which are potent promoters of ROS. Oxidation depletes membrane protein content, deforms RBCs, and disturbs microcirculation (1-4). It is also implicated in haemolysis (5).
Haemolysis has long been used to measure free radical damage and counteraction by antioxidants. It is useful for screening for oxidising or antioxidising agents (6). Several herbal secondary metabolites such as flavonoids have been found to protect cells from oxidative damage. These compounds have been evidenced to stabilise RBC membrane by scavenging free radicals and reducing lipid peroxidation $(3,7)$.

Herbs are a rich source of flavonoids, phenolic acids, and alkaloids, some of which act as antioxidants (7-10). Nabavi et al. (9) studied the antioxidant and antihaemolytic activities of Ferula foetida in RBCs and a few other interesting studies have recently been reported, indicating the protective effects of plant 
extracts against oxidative damage in intact $\mathrm{RBC}$ membranes $(7,9,10)$.

The aim of this study was to investigate the antihaemolytic activity of herbal extracts from ten plants and identify promising alternatives to treating diseases associated with haemolysis. We also wanted to see which of the three extraction methods used ultrasound-assisted extraction (UAE), Soxhlet extraction (SO), and percolation (PE) yielded more efficient extracts. Our third aim was to verify the protective effects (as claimed in literature, cf. 11, 12) of polyphenols extracted from two plants against oxidative stress. With these aims, we prepared 30 herbal extracts and evaluated their capacity to suppress $\mathrm{RBC}$ haemolysis. In addition, we also measured the haemolytic activity of the most potent extracts in the absence of $\mathrm{H}_{2} \mathrm{O}_{2}$ in order to determine their own oxidative toxicity to RBCs.

\section{MATERIALS AND METHODS}

\section{Chemicals}

Formic acid, $30 \%$ hydrogen peroxide, and vitamin $\mathrm{C}$, which was used as reference compound, were purchased from Merck (Darmstadt, Germany). All solvents were of analytical grade or purer. Distilled deionised water was prepared with the Ultrapure ${ }^{\mathrm{TM}}$ water purification system. Vitamin C was used in the same concentrations as the plant extracts.

\section{Plants}

Ten plant species were collected and their identity verified by Dr Bahman Eslami (Islamic Azad University of Qaemshahr, Iran). The voucher specimens were deposited in the herbarium of the Department of Pharmacognosy, School of Pharmacy, Mazandaran University of Medical Sciences. Table 1 lists the plants, the parts, and the methods used for extraction. Plant materials were dried under dark conditions at room temperature for 2-3 weeks. The dry materials were milled, obtaining 2-3 mm particles.

\section{Extraction methods}

Extraction is the first important step in the recovery and purification of active ingredients from plants. The aim is to provide maximum yield and the highest quality of target compounds in the shortest time and at the lowest cost possible. Many techniques, such as conventional solvent extraction, microwave-assisted, and ultrasound-assisted extraction, have been developed to extract active ingredients (13). In this study, we opted for the three most common extraction methods: percolation, Soxhlet extraction, and ultrasound-assisted extraction.

For percolation, we used methanol to treat known amounts of each plant part at room temperature as described elsewhere $(14,15)$. The resulting extracts were concentrated over a rotary vacuum (Heidolph, Schwabach, Germany) at $35-40{ }^{\circ} \mathrm{C}$ until a crude solid extract was obtained, which was then freeze-dried (MPS-55 freeze-drier, Operon Co., Ltd., Gimpo, South Korea) for complete solvent removal.

In Soxhlet extraction, powdered samples were treated with methanol and extracted in an ISOLAB extractor (Wertheim, Germany) for $24 \mathrm{~h}$. The extracts were then concentrated in a rotary evaporator (Heidolph, Germany) until the solvent was removed. The extracts were freeze-dried for complete solvent removal $(14,15)$.

In ultrasound-assisted extraction samples were treated with methanol and placed in an ultrasonic cleaning bath (Tecna3, Bologna, Italy) at a frequency of $100 \mathrm{kHz}$ and temperature of $25 \pm 3{ }^{\circ} \mathrm{C}$ for $1 \mathrm{~h}$ to yield extracts, which were then separated from the residue by filtration and concentrated in a rotary evaporator until crude solid extracts were obtained. Followed freeze-drying for complete solvent removal (16).

\section{Polyphenol extraction}

Literature suggests that polyphenols act as antioxidants and protect RBCs against oxidative damage $(11,12,17)$. These compounds were extracted from samples according to our recently published paper (16). The extraction was performed twice at $20^{\circ} \mathrm{C}$ in a shaking incubator $(115 \mathrm{~W}$, Promax 1020 , Heidolph, Germany). The extraction time was $30 \mathrm{~min}$ and the extracting solvent was $100 \mathrm{~mL}$ of methanol/ acetone/water (3.5/3.5/3) containing $1 \%$ formic acid. Extracts were combined and filtered through two layers of cheesecloth. The collected filtrate was centrifuged at $7000 \mathrm{~g}$ for $15 \mathrm{~min}$. The supernatant was collected and evaporated under vacuum at $35-40{ }^{\circ} \mathrm{C}$ to remove methanol and acetone. Lipophilic pigments were then eliminated from the aqueous phase by two successive extractions in a separatory funnel with a twofold volume of petroleum ether. The aqueous phase was collected and further extracted by the equal volume of ethyl acetate three times in the separatory funnel. Three ethyl acetate phases were collected and 
Table 1 Plant names, extraction methods, part used, and Herbarium numbers

\begin{tabular}{lccc} 
Plant name & Extraction method & Part used & $\begin{array}{c}\text { Herbarium } \\
\text { number }\end{array}$ \\
\hline Orobanche orientalis (broomrape) & Ultrasonic/Soxhlet & Aerial parts & MH1001 \\
\hline Cucumis melo (muskmelon) & Percolation/Soxhlet/Ultrasonic & Leaf/Fruit & MH1002 \\
\hline Albizia julibrissin (Persian silk tree) & Ultrasonic/Soxhlet/ Percolation & Leaf/Flower & MH1003 \\
\hline Galium verum (lady's bedstraw) & Percolation & Aerial parts & MH1004 \\
\hline $\begin{array}{lccl}\text { Scutellaria tournefortii (skullcap) } \\
\text { Crocus caspius (crocus) }\end{array}$ & Percolation/Soxhlet/Polyphenol & Aerial parts & MH1010 \\
\hline Sambucus ebulus (danewort) & Percolation/Polyphenol/Ultrasonic & Aerial parts/Bulb & MH1008 \\
\hline $\begin{array}{l}\text { Danae racemosa (Alexandrian or } \\
\text { poet's laurel) }\end{array}$ & Soxhlet/Percolation/Ultrasonic & Flower & MH1009 \\
\hline $\begin{array}{l}\text { Rubus fruticsos (blackberry) } \\
\text { Artemisia absinthium (wormwood) }\end{array}$ & Soxhlet/Percolation/ Ultrasonic & Aerial parts & MH1011 \\
\hline
\end{tabular}

concentrated over a rotary vacuum until a crude solid extract was obtained, which was then freeze-dried for complete solvent removal.

\section{Preparation of mice RBCs}

A total of 30 male Swiss albino mice (20-25 g, Institute Pasteur of Iran) were used in this study. The animals were housed in standard cages with free access to food (standard laboratory rodent chow) and water. The animal house temperature was maintained at $23 \pm 3{ }^{\circ} \mathrm{C}$ with a 12 -h light/12-h dark cycle (light on from 06:00 to 18:00 h). All of the experiments were conducted between 10:00 and 14:00 h. The experimental procedure was conducted in accordance with the NIH Guide for the Care and Use of Laboratory Animals (18).

The mice were killed under anaesthesia and their blood collected by heart puncture in heparinised tubes. RBCs were isolated and stored according to the method described by Ebrahimzadeh et al. (7). Briefly, blood samples were centrifuged $(1500 \mathrm{~g}, 10 \mathrm{~min})$, and RBCs separated from plasma and buffy coat and washed three times by centrifugation $(1500 \mathrm{~g}, 5 \mathrm{~min})$ in 10 volumes of $10 \mathrm{mmol} \mathrm{L}^{-1}$ phosphate buffered saline (pH 7.4; PBS). The supernatant and buffy coats of white cells were carefully removed with each wash. Washed RBCs were stored at $4{ }^{\circ} \mathrm{C}$ and used within $6 \mathrm{~h}(19)$.

\section{Antihaemolytic activity assay}

This assay is useful for screening for agents and their metabolites that have an oxidising or antioxidising activity (11). Peroxides such as $\mathrm{H}_{2} \mathrm{O}_{2}$ and cumene hydroperoxide (7), protein denaturation, and heat shock-induced damage have all been extensively studied in biological membranes $(7,20,21)$.

The antihaemolytic activity of the extracts in our study was determined as described by Ebrahimzadeh et al. (7). Mice RBCs were diluted in PBS buffer to obtain a $4 \%$ suspension. The plant extracts were prepared in PBS buffer at five concentrations: 0.25, $0.5,1,2$, and $4 \mathrm{mg} \mathrm{mL}^{-1}$ (see our recently published paper under ref 22). To $2 \mathrm{~mL}$ of RBC suspension we added $1 \mathrm{~mL}$ of plant extract (in the above concentrations) and enough PBS to reach the final volume of $5 \mathrm{~mL}$. After $5 \mathrm{~min}$ of incubation at room temperature, $0.5 \mathrm{~mL}$ of $0.3 \% \mathrm{H}_{2} \mathrm{O}_{2}$ was added to induce oxidative degradation of membrane lipids and the mixture was shaken at $37^{\circ} \mathrm{C}$ for $240 \mathrm{~min}$. The samples were then centrifuged at $1500 \mathrm{~g}$ for $10 \mathrm{~min}$ and the resulting supernatant was removed and used to evaluate their haemolytic activity using a spectrophotometer (UVVisible EZ201, Perkin Elmer, Norwalk, CA, USA) at the absorbance wavelength of $540 \mathrm{~nm}$. RBC lysis in the presence of $\mathrm{H}_{2} \mathrm{O}_{2}$ and absence of a plant extract was considered as $100 \%$ haemolytic activity. Haemolysis in the presence extracts was calculated relative to this control haemolysis (22). Haemolysis inhibition was calculated as follows:

$$
\% \text { antihaemolysis }=\left[\left(\mathrm{A}_{\mathrm{o}}-\mathrm{A}_{1}\right) / \mathrm{A}_{\mathrm{o}}\right] \times 100
$$

where $\mathrm{A}_{\mathrm{o}}$ was the absorbance of control $\left(\mathrm{H}_{2} \mathrm{O}_{2}+\mathrm{RBC}\right.$, without extract) and $\mathrm{A}_{1}$ the absorbance in the presence 
of the extract or vitamin $\mathrm{C}$ as the reference antioxidant $(7,9,10)$ used in the same concentrations as the extracts $\left(0.25-4 \mathrm{mg} \mathrm{mL}^{-1}\right)$. Each set of experiments was performed in triplicate and the inhibitory activity expressed as percentage. Based on the inhibition, the plant extracts were classified into four groups: (a) neutral, with haemolysis similar to control, about $100 \%$; (b) weak, with haemolysis $>80 \%$ of the control; (c) potent, whose haemolysis was $<80 \%$; and (d) reverse, whose haemolytic activity was even higher than control $(>100 \%)$.

For potent extracts we calculated the half maximal inhibitory concentration $\left(\mathrm{IC}_{50}\right)$, which is the antioxidant concentration required to inhibit $50 \%$ of haemolysis caused by $\mathrm{H}_{2} \mathrm{O}_{2}$. We also measured the haemolytic activity of potent extracts in the absence of $\mathrm{H}_{2} \mathrm{O}_{2}$ in order to see if and how much oxidative damage they alone caused to RBCs. For this experiment, we only used the highest concentration, $4 \mathrm{mg} \mathrm{mL}^{-1}$.

\section{Total phenolic and flavonoid content}

Total phenolic content was determined using the Folin-Ciocalteu method (16). We first mixed sample extract $(0.5 \mathrm{~mL})$ with the Folin-Ciocalteu reagent ( $5 \mathrm{~mL}$, diluted with distilled water at the 1:10 ratio) for $5 \mathrm{~min}$ and then added aqueous $\mathrm{Na}_{2} \mathrm{CO}_{3}(4 \mathrm{~mL}$, $\left.1 \mathrm{~mol} \mathrm{~L}^{-1}\right)$. After $2 \mathrm{~h}$ of incubation at room temperature, we measured the absorbance of reaction with a doublebeam spectrophotometer (UV- Visible EZ201, Perkin Elmer, Norwalk, CA, USA) at $760 \mathrm{~nm}$. The standard curve was prepared with $0,50,100,150,200$, and $250 \mu \mathrm{g} \mathrm{mL}{ }^{-1}$ solutions of gallic acid in methanol and water $(50: 50, \mathrm{v} / \mathrm{v})$. Total phenol content is expressed as milligram of gallic acid equivalents (GAE) per one gram of extract.

Total flavonoid content was measured using the colourimetric aluminium chloride method (16). Briefly, $0.5 \mathrm{~mL}$ solutions of the extract in methanol were mixed with $1.5 \mathrm{~mL}$ of methanol, $0.1 \mathrm{~mL}$ of $10 \%$ aluminium chloride, $0.1 \mathrm{~mL}$ of $1 \mathrm{~mol} \mathrm{~L}^{-1}$ potassium acetate, and $2.8 \mathrm{~mL}$ of distilled water and left at room temperature for $30 \mathrm{~min}$. The absorbance of the reaction mixture was measured at $415 \mathrm{~nm}$. Total flavonoid content was calculated from a calibration curve which was prepared by quercetin solutions with methanol at concentrations ranging from 12.5 to $100 \mu \mathrm{g} \mathrm{mL}^{-1}$ and is expressed as milligram of quercetin equivalent $(\mathrm{QE})$ per one gram of extract.

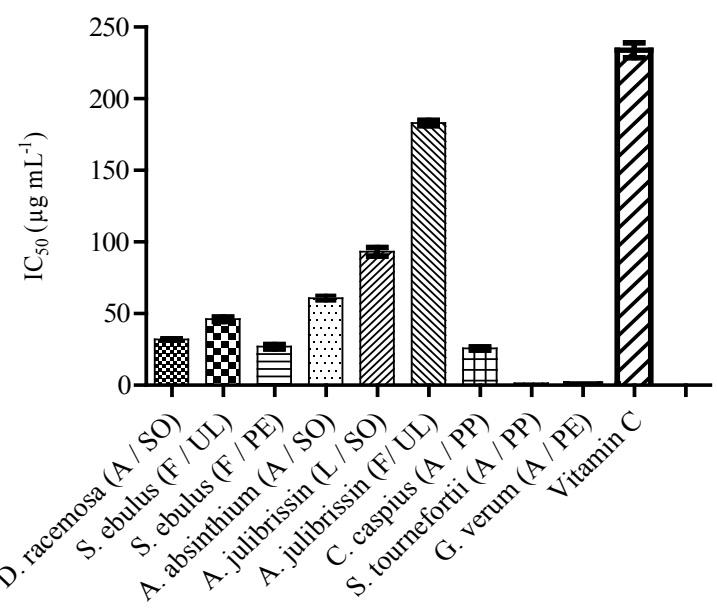

Figure $1 \mathrm{IC}_{50}$ of the most potent extracts with antihaemolytic activity (less is better). Vitamin $C$ served as reference compound.

A: aerial part; F: fruit; L; leaf; SO: Soxhlet extraction; PE: percolation; UAE: ultrasound-assisted extraction; PP: polyphenol fraction

\section{Statistical analysis}

The results of the antihaemolysis assays are presented as means of three replicate measurements \pm standard deviation (SD). The data were analysed using the analysis of variance (ANOVA) $(p<0.05)$ and grouped using Duncan's multiple range test. The $\mathrm{IC}_{50}$ values were calculated using linear regression analysis.

\section{RESULTS AND DISCUSSION}

Table 2 shows that the antihaemolytic activity of our extracts and extracted polyphenols varied a lot. The group with reverse effects (higher haemolysis than control) included C. melo (leaf/percolation, ultrasonic, and Soxhlet; fruit/Soxhlet and ultrasonic), A. julibrissin (leaf/ultrasonic; flower/Soxhlet), $S$. tournefortii (aerial parts/Soxhlet), O. orientalis (aerial parts/ultrasonic and Soxhlet), C. caspius (aerial parts/ percolation and ultrasonic; bulb/polyphenol), $A$. julibrissin (leaf/percolation; flower/percolation).

S. tournefortii (aerial parts/percolation) was the only neutral sample, showing no inhibitory effects on $\mathrm{H}_{2} \mathrm{O}_{2}$. Five samples, including S. ebulus (flower/ Soxhlet), R. fruticsos (leaf/percolation), A. julibrissin (flower/ultrasonic), C. melo (fruit/percolation), and $A$. absinthium (aerial parts/percolation) showed weak haemolysis inhibition. 
Table 2 The haemolytic activity of plants at different concentrations.

\begin{tabular}{|c|c|c|c|c|c|c|}
\hline \multirow{2}{*}{$\begin{array}{l}\text { Plant names } \\
\text { (part used) }\end{array}$} & \multicolumn{6}{|c|}{ Concentration $\left(\mathrm{mg} \mathrm{mL}^{-1}\right)$} \\
\hline & Method & 4 & 2 & 1 & 0.5 & 0.25 \\
\hline $\begin{array}{l}\text { S. tournefortii (aerial } \\
\text { parts) }\end{array}$ & Percolation & $100.0 \pm 0.81$ & $100.0 \pm 0.94$ & $100.0 \pm 0.95$ & $100.0 \pm 0.17$ & $100.0 \pm 0.26$ \\
\hline $\begin{array}{l}\text { S. tournefortii (aerial } \\
\text { parts) }\end{array}$ & Polyphenol & $35.8 \pm 0.76$ & $46.5 \pm 0.37$ & $48.5 \pm 0.85$ & $49.3 \pm 0.93$ & $97.6 \pm 0.69$ \\
\hline $\begin{array}{l}\text { S. tournefortii (aerial } \\
\text { parts) }\end{array}$ & Soxhlet & $114.2 \pm 0.62$ & $112.3 \pm 0.75$ & $111.2 \pm 0.81$ & $107.4 \pm 90$ & $97.2 \pm 0.63$ \\
\hline S. ebulus (flower) & Soxhlet & $85.3 \pm 0.93$ & $93.8 \pm 0.68$ & $92.5 \pm 0.82$ & $93.1 \pm 0.57$ & $94.2 \pm 0.58$ \\
\hline R. fruticsos (leaf) & Percolation & $87.5 \pm 0.72$ & $97 \pm 0.68$ & $98.1 \pm 0.59$ & $99.3 \pm 0.39$ & $100.2 \pm 0.75$ \\
\hline C. melo (fruit) & Percolation & $96.4 \pm 0.94$ & $98.2 \pm 0.83$ & $99.2 \pm 0.07$ & $99.5 \pm 0.09$ & $99.6 \pm 0.59$ \\
\hline C. melo (fruit) & Soxhlet & $108.0 \pm 0.51$ & $107.8 \pm 1.01$ & $104.0 \pm 0.68$ & $100.1 \pm 0.71$ & $97.2 \pm 0.91$ \\
\hline C. melo (fruit) & Ultrasonic & $121.4 \pm 0.55$ & $120.5 \pm 1.12$ & $119.3 \pm 0.95$ & $107.5 \pm 0.22$ & $87.5 \pm 0.61$ \\
\hline C. melo (leaf) & Percolation & $121.1 \pm 0.80$ & $119.3 \pm 0.29$ & $114.1 \pm 0.45$ & $112.4 \pm 0.98$ & $111.9 \pm 0.37$ \\
\hline C. melo (leaf) & Soxhlet & $119.9 \pm 0.12$ & $117.4 \pm 0.65$ & $115.8 \pm 0.26$ & $111.6 \pm 0.71$ & $101.4 \pm 0.31$ \\
\hline C. melo (leaf) & Ultrasonic & $106.9 \pm 0.47$ & $102.7 \pm 1.01$ & $97.4 \pm 0.04$ & $91.5 \pm 0.57$ & $88.8 \pm 0.06$ \\
\hline $\begin{array}{l}\text { A. absinthium (aerial } \\
\text { parts) }\end{array}$ & Percolation & $87.7 \pm 0.47$ & $83.2 \pm 0.48$ & $88.1 \pm 0.19$ & $91.8 \pm 0.69$ & $91.2 \pm 0.19$ \\
\hline $\begin{array}{l}\text { D. racemosa (aerial } \\
\text { parts) }\end{array}$ & Soxhlet & $65.5 \pm 0.39$ & $80 \pm 0.58$ & $80.5 \pm 0.96$ & $83.3 \pm 0.83$ & $94.4 \pm 1.00$ \\
\hline S. ebulus (flower) & Ultrasonic & $79.3 \pm 0.41$ & $84.1 \pm 0.29$ & $86.6 \pm 0.59$ & $91.6 \pm 0.18$ & $98.4 \pm 0.09$ \\
\hline S. ebulus (flower) & Percolation & $72.3 \pm 0.16$ & $78.5 \pm 0.68$ & $86.6 \pm 0.71$ & $98.6 \pm 0.56$ & $99.8 \pm 0.26$ \\
\hline $\begin{array}{l}\text { A. absinthium (aerial } \\
\text { parts) }\end{array}$ & Ultrasonic & $75.9 \pm 1.08$ & $88.6 \pm 0.91$ & $90 \pm 0.99$ & $90.7 \pm 0.08$ & $95.2 \pm 0.83$ \\
\hline $\begin{array}{l}\text { A. absinthium (aerial } \\
\text { parts) }\end{array}$ & Soxhlet & $74.9 \pm 0.13$ & $85 \pm 0.76$ & $91.4 \pm 034$ & $95.1 \pm 0.98$ & $98.9 \pm 0.80$ \\
\hline A. julibrissin (leaf) & Soxhlet & $62.2 \pm 0.38$ & $83.1 \pm 0.85$ & $86.1 \pm 0.82$ & $92.9 \pm 0.94$ & $100.1 \pm 0.09$ \\
\hline A. julibrissin (flower) & Ultrasonic & $82.1 \pm 0.09$ & $89.2 \pm 0.17$ & $92.6 \pm 0.57$ & $94.4 \pm 0.67$ & $98.8 \pm 0.61$ \\
\hline A. julibrissin (flower) & Soxhlet & $129.7 \pm 0.43$ & $127.4 \pm 0.09$ & $121.0 \pm 0.81$ & $120.1 \pm 0.18$ & $110.6 \pm 0.72$ \\
\hline A. julibrissin (leaf) & Ultrasonic & $123.8 \pm 0.91$ & $118.8 \pm 0.85$ & $116.8 \pm 0.47$ & $103.2 \pm 0.70$ & $95.4 \pm 0.58$ \\
\hline A. julibrissin (leaf) & Percolation & $126.2 \pm 0.63$ & $124.4 \pm 0.45$ & $117.0 \pm 0.94$ & $98.7 \pm 0.51$ & $90.6 \pm 0.09$ \\
\hline A. julibrissin (flower) & Percolation & $92.3 \pm 0.33$ & $90.1 \pm 0.83$ & $88.0 \pm 0.66$ & $86.8 \pm 0.41$ & $83.4 \pm 0.91$ \\
\hline C. caspius (aerial parts) & Polyphenol & $67.7 \pm 0.41$ & $75.5 \pm 0.96$ & $85.5 \pm 1.40$ & $88.8 \pm 0.74$ & $96.1 \pm 0.90$ \\
\hline C. caspius (bulb) & Polyphenol & $97.7 \pm 0.59$ & $89.1 \pm 0.19$ & $75.9 \pm 0.07$ & $75.3 \pm 0.94$ & $67.9 \pm 0.79$ \\
\hline C. caspius (aerial parts) & Ultrasonic & $114.0 \pm 0.41$ & $113.9 \pm 0.73$ & $110.8 \pm 0.84$ & $109.4 \pm 0.69$ & $104.8 \pm 0.05$ \\
\hline C. caspius (aerial parts) & Percolation & $130.6 \pm 0.38$ & $112.1 \pm 0.69$ & $109.4 \pm 0.19$ & $104.9 \pm 0.81$ & $100.3 \pm 0.77$ \\
\hline G. verum (aerial parts) & Percolation & $34.5 \pm 0.27$ & $45.5 \pm 0.06$ & $48.8 \pm 0.54$ & $52.0 \pm 0.83$ & $65.4 \pm 0.91$ \\
\hline $\begin{array}{l}\text { O. orientalis (aerial } \\
\text { parts) }\end{array}$ & Soxhlet & $94.0 \pm 0.41$ & $91.4 \pm 0.49$ & $91.4 \pm 0.83$ & $85.2 \pm 0.91$ & $80.4 \pm 0.29$ \\
\hline $\begin{array}{l}\text { O. orientalis (aerial } \\
\text { parts) }\end{array}$ & Ultrasonic & $128.2 \pm 1.30$ & $117.2 \pm 1.01$ & $112.4 \pm 0.91$ & $110.9 \pm 0.66$ & $86.5 \pm 0.82$ \\
\hline Vitamin C & & $83.3 \pm 0.11$ & $90.6 \pm 0.10$ & $98.7 \pm 0.26$ & $99.3 \pm 0.38$ & $99.8 \pm 0.51$ \\
\hline
\end{tabular}


The remaining nine samples, namely $D$. racemosa (aerial parts/Soxhlet), S. ebulus (flower/ultrasonic and percolation), A. absinthium (aerial parts/ultrasonic and Soxhlet), A. julibrissin (leaf/Soxhlet), C. caspius (aerial parts/polyphenol), S. tournefortii (aerial parts/ polyphenol), and G. verum (aerial parts/percolation) showed strong antihaemolytic activity. These nine were also more potent than the reference vitamin $\mathrm{C}$ $\left(\mathrm{IC}_{50}=235 \pm 5.26 \mu \mathrm{g} \mathrm{mL}^{-1}\right)$. Their $\mathrm{IC}_{50}$ is shown in Figure 1. The most potent were G. verum (aerial parts/ percolation) and $S$. tournefortii (aerial parts/ polyphenol), whose respective $\mathrm{IC}_{50}$ of 1.32 and $2.08 \mu \mathrm{g} \mathrm{mL}^{-1}$ was significantly lower than that of vitamin $\mathrm{C}(p<0.001)$. Their antihaemolytic activity grew with concentration.

The haemolytic activity of the nine potent compounds in the absence of $\mathrm{H}_{2} \mathrm{O}_{2}$ was below $7 \%$ (data not shown), which suggests that they are not toxic. Unlike A.julibrissin and C. melo, whose activity in most cases intensified $\mathrm{H}_{2} \mathrm{O}_{2}$-induced haemolysis.

C. caspius showed contradictory findings, as its polyphenol fraction extracted from the aerial parts strongly inhibited $\mathrm{H}_{2} \mathrm{O}_{2}$-induced haemolysis, but its extracts obtained by percolation and ultrasound intensified it.

Although the Soxhlet extract of S. ebulus showed weak antihaemolytic activity, extracts obtained with other methods were potent against haemolysis. Similarly, percolation rendered A. absinthium weak while ultrasound and Soxhlet yielded potent antihaemolytic extracts. Clearly, extraction methods deserve a more comprehensive research in this respect.

Various studies have recently investigated the potential of phenols against oxidative damage in RBCs, suggesting a possible interaction between flavonoids and RBC membrane lipids and proteins that are generally targeted by lipid peroxidation (12, 17, 23). Divya et al. reported (24) considerable antihaemolytic activity of the methanolic extracts of Bombax ceiba pentandra fruit and spike (14.57 and $19.14 \%$ haemolysis vs. $100 \%$ for negative control, respectively) owing perhaps to their high phenol and flavonoid content and good antioxidant activity. Deepinderjeet et al. (25) also related the antihaemolytic effects of Calendula officinalis $\left(\mathrm{IC}_{50}=120.5 \pm 0.4\right)$, Juglans regia $\left(\mathrm{IC}_{50}=148.8 \pm 1.4\right)$, and Ficus bengalensis $\left(\mathrm{IC}_{50}=214.1 \pm 1.5 \mu \mathrm{g} \mathrm{mL}^{-1}\right)$ to high flavonoid content and good antioxidant activity. A report by Yang et al. (26) showed high haemolysis inhibition by fermented soybean meal extract at concentrations of $2-10 \mathrm{mg} \mathrm{mL}^{-1}$ $\left(\mathrm{IC}_{50}\right.$ value $\left.4.599 \mathrm{mg} \mathrm{mL}^{-1}\right)$. The extract also had potent in vivo antioxidant activity. Our phenol and flavonoid findings are shown in Table 3. Antihaemolytic activity strongly correlated with total phenolic content $\left(r^{2}=0.693\right)$ but not with flavonoid content $\left(r^{2}=0.029\right)$. Our findings are in agreement with studies showing that polyphenols protect RBCs from oxidative stress or increase their resistance to oxidative damage (12, 27). They also confirm the correlation between total phenolic content and antioxidant activity from studies on different foodstuffs such as fruit and vegetables (28-30).

To conclude, the nine extracts that showed high antihaemolytic activity in our study, G. verum (percolation) and S. tournefortii (polyphenol fraction) could serve as easily accessible sources of natural antioxidants for the pharmaceutical industry.

\section{Acknowledgements}

This research was supported by a grant from the Pharmaceutical Sciences Research Center, Mazandaran University of Medical Sciences, Iran.

Table 3 Phenol and flavonoid content of the nine most potent extracts

\begin{tabular}{|c|c|c|c|c|}
\hline Plant name & $\begin{array}{c}\text { Extraction } \\
\text { method }\end{array}$ & Part used & $\begin{array}{l}\text { Phenol content } \\
\text { / } \text { mg g-1 of extract }^{-1}\end{array}$ & $\begin{array}{l}\text { Flavonoid content } \\
/ \mathbf{m g ~ g}^{-1} \text { of extract }\end{array}$ \\
\hline A. julibrissin & Ultrasonic & Flower & 340 & 136 \\
\hline A. julibrissin & Soxhlet & Leaf & 688 & 121 \\
\hline G. verum & Percolation & Aerial parts & 329 & 56 \\
\hline S. tournefortii & Polyphenol & Aerial parts & 735 & 151 \\
\hline C. caspius & Polyphenol & Aerial parts & 191 & 82 \\
\hline S. ebulus & Percolation & Flower & 56 & 14.5 \\
\hline D. racemosa & Soxhlet & Aerial parts & 256 & 131 \\
\hline S. ebulus & Ultrasonic & Flower & 81 & 52 \\
\hline A. absinthium & Soxhlet & Aerial parts & 267 & 136 \\
\hline
\end{tabular}

${ }^{a}$ gallic acid equivalents of extract; ${ }^{b}$ quercetin equivalent; $\mathrm{mg} \mathrm{g}^{-1}$ of extract 


\section{REFERENCES}

1. Yang H, Chen S, Chang N, Chang J, Lee M, Tsai P, Fu HH, Kao WW, Chiang HC, Wang HH, Hseu YC. Protection from oxidative damage using Bidens pilosa extracts in normal human erythrocytes. Food Chem Toxicol 2006;44:1513-21. PMID: 16765500

2. Rice-Evans C, Omorphos SC, Baysal E. Sickle cell membranes and oxidative damage. Biochem J 1986;237:2659. PMCID: PMC1146974

3. Yu L. Free radical scavenging properties of conjugated linoleic acids. J Agric Food Chem 2001;49:3452-6. doi: 10.1021/jf010172v

4. Flynn TP, Allen DW, Johnson GJ, White JG. Oxidant damage of the lipids and proteins of the erythrocyte membranes in unstable hemoglobin disease. Evidence for the role of lipid peroxidation. J Clin Invest 1983;71:1215-23. doi: 10.1172 JCI110870

5. Ko FN, Hsiao G, Kuo YH. Protection of oxidative hemolysis by demethyldiisoeugenol in normal and beta-thalassemic red blood cells. Free Radic Biol Med 1997;22:215-22. doi: 10.1016/j.fct.2006.04.006

6. Djeridane A, Yousfi M, Nadjemi B, Vidal N, Lesgards JF, Stocker P. Screening of some Algerian medicinal plants for the phenolic compounds and their antioxidant activity. Eur Food Res Technol 2006;224:801-9. doi: 10.1007/s00217006-0361-6

7. Ebrahimzadeh MA, Nabavi SF, Nabavi SM, Eslami B. Antihemolytic and antioxidant activities of Allium paradoxum. Cent Eur J Biol 2010;5:338-45. doi: 10.2478/ s11535-010-0013-5

8. Ebrahimzadeh MA, Ehsanifar S, Eslami B. Sambucus ebulus elburensis fruits: A good source for antioxidants. Pharmacogn Mag 2009;4:213-8.

9. Nabavi S, Ebrahimzadeh M, Nabavi S, Eslami B, Dehpour A. Antioxidant and antihaemolytic activities of Ferula foetida regel (Umbelliferae). Eur Rev Med Pharmacol Sci 2011;15:157-64. PMID: 21434482

10. Ebrahimzadeh MA, Nabavi SF, Eslami B, Nabavi SM. Antioxidant and antihemolytic potentials of Physosperum cornubiense (L.) DC. Pharmacologyonline 2009;3:394-403.

11. Costa RM, Magalhães AS, Pereira JA, Andrade PB, Valentão P, Carvalho M, Silva BM. Evaluation of free radical scavenging and antihemolytic activities of quince (Cydonia oblonga) leaf: a comparative study with green tea (Camellia sinensis). Food Chem Toxicol 2009;47: 860-865. doi:10.1016/j.fct.2009.01.019

12. Magalhaes AS, Silva BM, Pereira JA, Andrade PB, Valentao $\mathrm{P}$, Carvalho M. Protective effect of quince (Cydonia oblonga Miller) fruit against oxidative hemolysis of human erythrocytes. Food Chem Toxicol 2009;47:1372-7. doi: 10.1016/j.fct.2009.03.017

13. Sun J, Chu YF, Wu X, Liu R. Antioxidant and antiproliferative activities of common edible nut seeds. J Agric Food Chem 2002;50:7449-54. doi: 10.1016/j.lwt.2008.07.007

14. Jamshidi M, Hashemi Z, Ebrahimzadeh MA. Evaluation of antioxidant activities of Laurus nobilis L. (Lauraceae) fruits, Impact of extraction methods. World Sci J 2013;1:79-87.

15. Forouzani M, Askari M, Ebrahimzadeh MA. Evaluation of three methods for the extraction of antioxidants from Cucumis melo L. fruit and leaves. Int J Forest Soil Erosion 2013;3:95-9.
16. Rabiei Kh, Bekhradnia S, Nabavi SM, Nabavi SF, Ebrahimzadeh MA. Antioxidant activity of polyphenol and ultrasonic extracts from fruits of Crataegus pentagyna subsp. elburensis. Nat Prod Res 2012;26:2353-7. doi: 10.1080/14786419.2012.658799

17. Ferrali M, Signorini C, Caciotti B, Sugherini L, Ciccoli L, Giachetti D, Comporti M. Protection against oxidative damage of erythrocyte membrane by the flavonoid quercetin and its relation to iron chelating activity. FEBS Lett 1997;416:123-9. doi: 10.1016/S0014-5793(97)01182-4

18. National Institutes of Health (NIH). Guide for the Care and Use of Laboratory Animals. NIH Publication No. 85-23. Revised 1985.

19. Ebrahimzadeh MA, Eslami S, Nabavi SM, Nabavi SF, Eslami B. Antioxidant and antihemolytic activities of leontodon hispidus. Biotechnol Biotechnol Eq 2010:24:2127-31. doi: 10.2478/V10133-010-0090-7

20. Carvalho M, Ferreira PJ, Mendes VS, Silva R, Pereira JA, Jerónimo C, Silva BM. Human cancer cell antiproliferative and antioxidant activities of Juglans regia L. Food Chem Toxicol 2010;48:441-7. doi:_10.1016/j.fct.2009.10.043

21. Zou CG, Agar NS, Jones GL. Oxidative insult to human red blood cells induced by free radical initiator AAPH and its inhibition by a commercial antioxidant mixture. Life Sci 2001;69:75-86. doi: 10.1016/S0024-3205(01)01112-2

22. Ebrahimzadeh MA, Nabavi SF, Nabavi SM. Antihemolytic and antioxidant activity of Hibiscus esculenus leaves. Pharmacologyonline 2009;2:1097-105.

23. Chaudhuri S, Banerjee A, Basu K, Sengupta B, Sengupta PK. Interaction of flavonoids with red blood cell membrane lipids and proteins: Antioxidant and antihemolytic effects. Int J Biol Macromol 2007;41:42-8. doi: 10.1016/j. ijbiomac.2006.12.003

24. Divya N, Nagamani JE, Suma Prabhu. Antioxidant and antihemolytic activities of bombax ceiba pentandra spike and fruit extracts. Int J Pharm Pharmac Sci 2012;4(Suppl 5):311-5.

25. Deepinderjeet SJ, Harshit Sh, Shruti RM. Antihemolytic and protein denaturation inhibition: A comparative study of plants of Indian origin. Inventi Impact: Ethnopharmacology 2013;2:795-805.

26. Yang X, Chen J, Zhang Ch, Chen H, Liu Y. Evaluation of antioxidant activity of fermented soybean meal extract. Afr J Pharm Pharmacol 2012;6:1774-81. doi: 10.5897/ AJPP12.392

27. Chakraborty D, Shah B. Antimicrobial, anti-oxidative and anti-hemolytic activity of Piper betel leaf extracts. Int J Pharm Pharmaceut Sci 2011;3(Suppl 3):192-9.

28. Kiselova Y, Ivanova D, Chervenkov T, Gerova D, Galunska $\mathrm{B}$, Yankova T. Correlation between the in vitro antioxidant activity and polyphenol content of aqueous extracts from Bulgarian herbs. Phytother Res 2006;20:961-5. doi: 10.1002/ ptr.1985

29. Ghasemi K, Ghasemi Y, Ebrahimzadeh MA. Antioxidant activity, phenol and flavonoid contents of 13 Citrus species peels and tissues. Pak J Pharm Sci 2009;22:277-81. PMID: 19553174

30. Jayaprakasha GK, Patil BS. In vitro evaluation of the antioxidant activities in fruit extracts from citron and blood orange. Food Chem 2007;101:410-8. doi: 10.1016/j. foodchem.2005.12.038 


\title{
Sažetak
}

\section{Antihemolitička aktivnost trideset biljnih ekstrakata u mišjim eritrocitima}

Reaktivni kisikovi spojevi (ROS) mogu dovesti do hemolize te u konačnici do bolesti poput talasemije i anemije srpastih stanica. Takvo se djelovanje može ublažiti ili spriječiti terapijskim djelovanjem antihemolitika. Cilj je ovog istraživanja bio izdvojiti biljke koje najuspješnije sprječavaju hemolizu uzrokovanu reaktivnim kisikovim spojevima. U tu smo svrhu pripremili 30 ekstrakata biljaka poznatih po svojem antioksidacijskom djelovanju: Orobanche orientalis G. Beck, Cucumis melo L., Albizzia julibrissin Durazz, Galium verum L., Scutellaria tournefortii Benth, Crocus caspius Fischer \& Meyer, Sambucus ebulus L, Danae racemosa L., Rubus fruticsos L. te Artemisia absinthium L. Rabili smo tri uobičajene ekstrakcijske metode (perkolacija, Soxhlet i ultrazvučna ekstrakcija) kako bismo utvrdili utječe li metoda na anihemolitičku aktivnost ekstrakta te smo u nekoliko uzoraka ekstrahirali polifenole kako bi se vidjelo koliko je ta aktivnost povezana s njihovom razinom. Antihemolitičku smo aktivnost mjerili u mišjim eritrocitima i usporedili je s onom vitamina $C$, koji je poznati antioksidans. Izdvojeno je devet ekstrakata sa snažnijom aktivnosti od vitamina C, od kojih su ekstrakti G. verum (zračni dijelovi/perkolacija) odnosno S. tournefortii (nadzemni dijelovi/polifenoli) bili najsnažniji, s inhibicijskom koncentracijom $\left(\mathrm{IC}_{50}\right.$ ) od 1,32 odnosno $2.08 \mu \mathrm{g} \mathrm{mL}^{-1}$. Inhibicija hemolize ovisila je o koncentraciji ekstrakta te o metodi ekstrakcije. Ove bi biljke mogle poslužiti farmaceutskoj industriji kao lako dostupni izvori prirodnih antioksidansa.

KLJUČNE RIJEČI: fenoli; Galium verum; perkolacija; Scutellaria tournefortii; Soxhlet; ultrazvučna ekstrakcija; vodikov peroksid

\section{CORRESPONDING AUTHOR:}

\author{
Mohammad Ali Ebrahimzadeh \\ Mazandaran University of Medical Sciences \\ School of Pharmacy \\ Sari, Iran \\ E-mail: zadeh20@gmail.com
}

